\title{
Neuroradiologinė epileptogeninių židinių diagnostika: 1,5T ir 3T magnetinio lauko stiprumo MRT tyrimu palyginimas
}

\section{Runkauskaité*}

T. Liakina**

\section{R. Mameniškiené***}

*Vilniaus universiteto Medicinos

fakulteto Klinikines medicinos

instituto Vaiku ligu klinika,

Vilniaus universiteto ligonines

Santaros kliniku filialas,

Vaiku ligonine

**Vilniaus universiteto Medicinos fakulteto Klinikines medicinos instituto Neurologijos

ir neurochirurgijos klinika,

Vilniaus universiteto ligoniness

Santaros kliniku

Neurologijos centras

\begin{abstract}
Santrauka. Ivadas. Epilepsija - ketvirta dažniausiai pasitaikanti neurologinè liga, kuriai būdingas ilgalaikis polinkis generuoti priepuolius dèl pernelyg didelio ar sinchroniško galvos smegenų neuronų aktyvumo. Magnetinio rezonanso tomografija (MRT) yra pagrindinis ir informatyviausias neurovizualinis metodas, diagnozuojant epileptogeninius židinius ir jų atskiras rūšis. Ypač svarbus detalus neurovizualinis galvos smegenų ištyrimas refrakterine epilepsija sergantiems pacientams, kuriems svarstoma chirurginio gydymo galimybè.

Darbo tikslas. Nustatyti, ar didesnio magnetinio lauko stiprumo MRT technologija susijusi su patikimesniu ir dažnesniu epileptogeninių židinių (ir atskirų jų rūšių) nustatymu.

Tiriamieji ir tyrimo metodai. İ tyrimą įtraukti epilepsija sergantys pacientai, kuriems galvos smegenų MRT tyrimas atliktas 1,5T ir 3T tomografais. Vertinti patologiniai radiniai ir ju nustatymo dažnumas atliekant galvos smegenų MRT tyrimą skirtingo magnetinio lauko stiprumo aparatais. Statistiškai reikšmingu skirtumu laikyta ir nulinė hipotezė $\left(\mathrm{H}_{0}\right)$ atmesta, kai $\mathrm{p}<0,05$. Duomenys apdoroti Microsoft Office Excel 2016 ir IBM SPSS Statistics v20 programomis.

Rezultatai. İ tyrimą įtraukti 164 (99 moterys ir 65 vyrai) pacientai. Nustatyta statistiškai reikšminga priklausomybė $(\mathrm{p}<0,001)$ tarp didesnio magnetinio lauko stiprumo MRT tyrimo ir patologinių radinių nustatymo dažnio, tačiau statistiškai reikšmingos priklausomybės $(\mathrm{p}=0,183)$ tarp didesnio magnetinio lauko stiprumo MRT tyrimo ir epileptogeninių židinių rūšies nustatymo dažnumo nerasta.

Išvados. 3T MRT dažniau ir patikimiau nustato patologinius su epilepsijos priepuoliais susijusius židinius, todèl rekomenduojama atlikti šį tyrimą epilepsija sergantiems pacientams arba tiems pacientams, kuriems ankstesnio 1,5T MRT tyrimo metu patologija nerasta arba gauti nevienareikšmiai rezultatai.
\end{abstract}

Raktažodžiai: epilepsija, židininė epilepsija, magnetinio rezonanso tomografija, 3T magnetinio rezonanso tomografija.

\section{IVADAS}

Epilepsijos diagnostika remiasi ne tik klinikiniais simptomais, bet ir detaliu priepuolio aprašymu (paciento ir šalia buvusių asmenų pasakojimais), bendruoju ir biocheminiu kraujo tyrimais, elektroencefalografijos (EEG), genetiniu

\author{
Adresas: \\ Dovile Runkauskaitè \\ Vilniaus universiteto ligonines \\ Santaros kliniku filialas, Vaiku ligonine \\ Santariškiu g. 7, LT-08406 Vilnius \\ El.paštas runkauskaite.do@gmail.com
}

ir vaizdinių tyrimų rezultatais. Renkant anamnezę apie ìvykusi epilepsijos priepuoli, reikia išsiaiškinti detales apie priepuolio pradžią (kaip prasidèjo priepuolis, ką tuo metu veikè pacientas, ar pacientas atsimena, kas vyko priepuolio metu, ir iš aplinkinių objektyvius duomenis apie paciento veido išraišką, kūno judesius bei pozą), priepuolio eigą ir pabaigą (ar pacientas prikando liežuvị, ar pasišlapino ir kaip greitai atsigavo po priepuolio). Kadangi net ir tikslaus priepuolių apibūdinimo nepakanka epilepsijos priežasčiai nustatyti, atliekami papildomi tyrimai. Kraujo tyrimai atliekami siekiant atmesti kitas galimas priepuolių priežastis, pavyzdžiui, hipoglikemiją, hiponatremiją, apsinuodijimus (švinu, anglies monoksidu) ir abstinencijos

(C) Neurologijos seminarai, 2018. Open Access. This article is distributed under the terms of the Creative Commons Attribution 4.0 International License CC-BY 4.0 (http://creativecommons.org/licenses/by/4.0/), which permits unrestricted use, distribution, and reproduction in any medium, provided you give appropriate credit to the original author(s) and the source, provide a link to the Creative Commons license, and indicate if changes were made. 
Lentelè. Standartizuotas MRT tyrimo protokolas, naudojamas epilepsijos diagnostikoje

\begin{tabular}{||l|l||}
\hline 3D T1 sagitalineje plokštumoje & $1 \mathrm{~mm}$ \\
\hline 3D T2-FLAIR sagitalinejje plokštumoje & $1 \mathrm{~mm}$ \\
\hline FLAIR sagitalinėje plokštumoje & $3 \mathrm{~mm}$ \\
\hline T2 ašinėje plokštumoje & $5 \mathrm{~mm}$ \\
\hline FLAIR koronarinèje plokštumoje & $3 \mathrm{~mm}$ \\
\hline T2 koronarinėje plokštumoje & $2 \mathrm{~mm}$ \\
\hline FLAIR ašinejje plokštumoje & $2 \mathrm{~mm}$ \\
\hline SWI & $1 \mathrm{~mm}$ \\
\hline
\end{tabular}

FLAIR - skysčių susilpnintos reversijos atkūrimas (angl. Fluid Attenuation Inversion Recovery), SWI - svertinis jautrumo vaizdavimas (angl. Susceptibility Weighted Imaging)

sindromą. Dalis epilepsijos sindromų yra susiję su genų aberacijomis, kurios nustatomos genetinio ištyrimo metu. EEG tyrimas fiksuoja galvos smegenų bioelektrinius pokyčius. Atsižvelgiant ị situaciją ir reikalingumą, atliekami ir kiti tyrimai, kaip antai, lumbalinè punkcija (neuroinfekcijų, autoimuninio ar paraneoplastinio encefalito atmetimui), elektrokardiograma (EKG) (kardiologinès priežasties atmetimui), miego monitoravimas ir kt. Vaizdo EEG, kurios metu siekiama užfiksuoti pacientui būdingą elektroklinikini priepuoli, yra laikoma „auksiniu“ epilepsijos diagnostikos standartu.

Dažniausi neurovizualizacijos tyrimai, kurie atliekami epilepsija sergantiems pacientams, yra galvos kompiuterinè tomografija (KT) ir galvos MRT. Nors abu šie tyrimai vaizduoja galvos smegenų struktūrą ir anomalijas, epilepsija sergantiems asmenims rekomenduojama atlikti MRT, kadangi šis tyrimas pateikia išsamesnę informaciją [1], jam būdinga gera baltosios ir pilkosios smegenų medžiagu skiriamoji geba, galimybè gauti vaizdus keliose ortogonalinėse plokštumose. Svarbu taikyti specialų MRT tyrimo protokolą. Jo metu naudojamas specialus sekų derinys, dèl kurio tiek 1,5T, tiek 3T galvos smegenų MRT tyrimų metu itin padidinamas signalo ir triukšmo santykis (angl. signal and noise ratio; SNR), suteikiantis geresnį struktūurų erdvinị vaizdavimą ir kontrastavimą. Šis derinys padidina tyrimo jautrumą ir iki 82-86 \% - židinio nustatymo tikimybę [2] (lentelè).

Be to, šie SNR patobulinimai leidžia ne tik tiksliau kiekybiškai įvertinti smegenų makrostruktūrinius, bet ir geriau vaizduoja smegenų mikrostruktūrinius pakitimus. Didesnio nei 1,5T magnetinio lauko stiprumo MRT tyrimas dar labiau padidina SNR. Tai lemia dar geresnę vaizdų erdvinę rezoliuciją ir kontrastą, lyginant su iprastiniu 1,5T galvos MRT tyrimu, todèl geriau vizualizuojamos žievès malformacijos [3]. 3T galvos smegenų MRT tyrimo sekų pasirinkimas priklauso nuo klinikos ir anksčiau atliktų tyrimų išvadų. Ypač svarbūs yra 1,5T galvos smegenų MRT tyrimų rezultatai. Naudojant kelias skenavimo sekas ir ịvairias vaizdavimo plokštumas, galima lengviau identifikuoti epileptogeninius židinius. Židinine epilepsija sergantiems asmenims turètų būti atliekamas mažiausiai 1,5T MRT tyrimas.
Refrakterine epilepsija sergantiems pacientams ypač informatyvūs ir svarbūs yra neurovizualiniai tyrimai, kadangi jie suteikia papildomų duomenų epilepsijos sindrominei diagnostikai, padeda nustatyti ligos priežastis ir prisideda prie patofiziologinių procesų suvokimo. Sunkia epilepsijos forma sergantiems pacientams neurovizualiniai tyrimai turètų būti atliekami didelès skiriamosios gebos magnetinio rezonanso tomografais, keliose plokštumose ir laikantis specialaus epilepsijos diagnostikos protokolo [4]. Be to, jie atlieka vieną iš pagrindinių vaidmenų, planuojant vaistais nekontroliuojamos epilepsijos chirurgini gydymą.

\section{DARBO TIKSLAS}

Nustatyti, ar didesnio magnetinio lauko stiprumo MRT technologija yra susijusi su patikimesniu ir dažnesniu epileptogeninių židinių (ir atskirų jų rūšių) nustatymu.

\section{TIRIAMIEJI IR METODAI}

Atlikta retrospektyvinė epilepsija sergančių pacientų skirtingos gebos galvos smegenų MRT tyrimų duomenų analizè. I tyrimą įtraukti pacientai, kuriems: 1) diagnozuota epilepsija, 2) atliktas ir gydytojo radiologo ịvertintas bent vienas 1,5T galvos smegenų MRT tyrimas, 3) atliktas ir gydytojo radiologo ịvertintas bent vienas 3T galvos smegenu MRT tyrimas. Registruoti visi pacientai, kuriems 2014-01-01 - 2018-03-31 atliktas galvos smegenų MRT tyrimas 3T MRT „Philips Achieva“" aparatu. Jeigu pacientui buvo atlikti keli pakartotiniai 1,5T ir 3T galvos smegenų MRT tyrimai, vertinami ir toliau tarpusavyje lyginami pacientų paskutiniojo $1,5 \mathrm{~T}$ ir po jo atlikto pirmojo $3 \mathrm{~T}$ galvos smegenų MRT tyrimų aprašymai, išvados ir gydytojo radiologo specializacija. Tiriamojo darbo metu buvo ịvertintos demografinès tiriamujų charakteristikos (amžius ir lytis), patologiniai radiniai ir jų nustatymo dažnumas, atliekant galvos smegenų MRT tyrimą 1,5T ir 3T MRT aparatais.

Pagal radinius, pacientų diagnostinių tyrimų išvadas sugrupavome ị 2 grupes: 1 grupei priskyrème MRT tyrimus, kuriuose patologijos nestebeta, 2 grupei - tyrimus, kuriuose stebèti patologiniai pakitimai. Skirstydami antrąją grupe pagal patologinius radinius ị pogrupius, vadovavomès I. Blümcke tyrime naudotu protokolu [5] ir radinius skirsteme taip: 1) hipokampo sklerozė; 2) žievès vystymosi malformacijos; 3) navikai; 4) kraujagyslinè patologija; 5) kita patologija; 6) daugiau nei viena patologija: žievès displazija ir navikas, hipokampo sklerozė ir žievès gliozè, hipokampo sklerozè ir kavernomos, navikas ir žievès gliozè, hipokampo sklerozè su žievès glioze bei polimikrogirija [5]. Kitai patologijai priskyrème žievès gliozes, leukoencefalopatiją, tuberomas, cistinius ir encefalitinius darinius.

Duomenys rinkti iš VU SK Elektroninės ligos istorijos (ELI) sistemos, apdoroti Microsoft Office Exel 2016 (nau- 


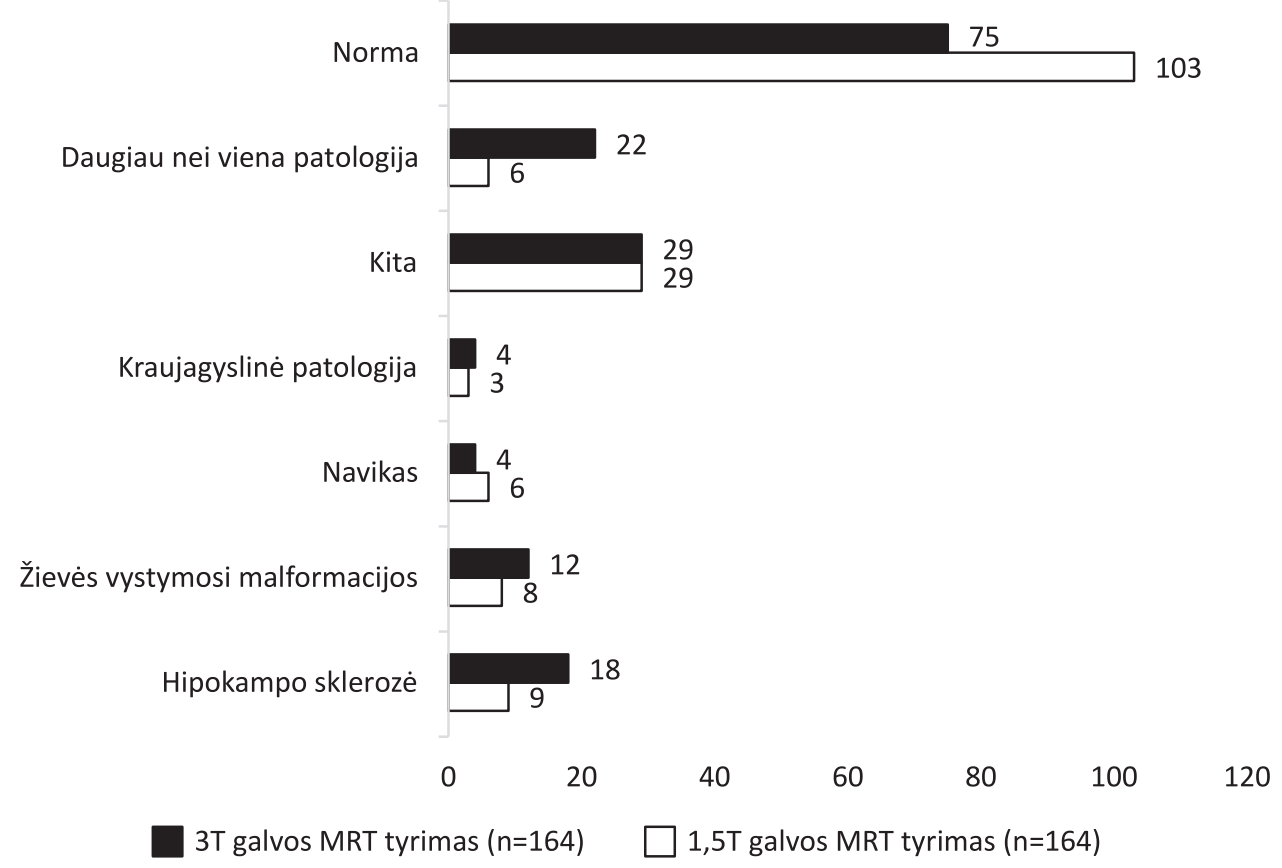

\section{Pav. 1,5T ir 3T galvos MRT tyrimų rezultatai}

dota apskaičiuojant ir vizualiai palyginant gautus rezultatus) ir IBM SPSS Statistics v20 programomis (statistinei duomenų analizei). Radinių ir jų atskirų rūšių pasiskirstymui tarp tiriamujjų nustatyti taikyta santykinio dažnio formule, apskaičiuotas santykinio dažnio pasikliautinasis intervalas; ryšys tarp skirtingo magnetinio lauko stiprumo galvos MRT tyrimų radinių (ir atskirų jų rūšių) bei MRT tyrimų vaizdus vertinusių gydytojų radiologų specializacijos nustatytas, naudojant neparametrini $\chi^{2}$ požymių nepriklausomumo statistinès analizės metodą (ryšio stiprumui vertinti remtasi Pearson Chi-Square kriterijumi); ryšys tarp pacientų galvos smegenų MRT tyrimų radinių (ir atskiru jų rūšių) bei skirtingo magnetinio lauko stiprumo MRT nustatytas, taikant neparametrinị $\chi^{2}$ požymių nepriklausomumo statistinị analizès metodą (ryšio stiprumui vertinti remtasi McNemar kriterijumi). Statistiškai reikšmingu skirtumu laikyta ir nulinė hipotezè $\left(\mathrm{H}_{0}\right)$ atmesta, kai $\mathrm{p}<0,05$.

\section{REZULTATAI}

Iš VUL SK ELI sistemos atrinkta 180 pacientų, kurie atitiko ịtraukimo ị tyrimą kriterijus. Analizuojant duomenis, paaiškejjo, kad 16 pacientų abu galvos MRT tyrimai buvo atliekami pooperacinių pokyčių kontrolei, todèl ị galutinę duomenų analizę jų neįtraukème. Tiriamojo darbo metu vertinti $164(100 \%)$ pacientu galvos MRT tyrimai: $99(60,4 \%)$ moterų ir 65 vyrų $(49,6 \%)$. Vidutinis pacientų amžius $1,5 \mathrm{~T}$ galvos smegenų MRT tyrimo metu buvo 34,6 $\pm 15,7$ (6-71) m., o 3T galvos smegenų MRT tyrimo metu - 38,7 $\pm 16,1(7-77) \mathrm{m}$. Vidutiniškai 3T galvos MRT tyrimas buvo atliekamas praejjus $48 \pm 31$ mèn. po 1 ,5T galvos MRT tyrimo. Trims tiriamiesiems pirmasis 3T galvos smegenų MRT tyrimas atliktas tais pačiais metais kaip ir paskutinis 1,5T galvos smegenų MRT tyrimas, o 2 tiriamiesiems - praejjus 132 mėn. nuo paskutinio 1,5T galvos MRT tyrimo.

Vertindami galvos smegenų MRT tyrimų vaizdus nagrinejjusius gydytojus radiologus, turinčius epilepsijos diagnostikos patirties, nustatème, kad 159 iš 164 vaizdų, atliktų 1,5T magnetinio rezonanso tomografu, ịvertino bendrosios specializacijos gydytojai radiologai ir tik 5 vaizdus neuroradiologai, t. y. gydytojai radiologai, turintys radiologinès epilepsijos diagnostikos patirties. Tačiau didžiają dali - net 137 pacientų - vaizdų, atliktų 3 T magnetinio rezonanso tomografu, ivertino ir apraše radiologinès epilepsijos diagnostikos patirties turintys gydytojai radiologai.

Atlikus tyrimus 1,5T magnetinio rezonanso tomografu, patologiniai pakitimai buvo nustatyti 61 pacientui (103 tyrimai buvo vertinti kaip „,be pakitimu“), o pakartotinis tyrimas $3 \mathrm{~T}$ magnetinio rezonanso tomografu patologinius pokyčius nustatė 89 pacientams (75 - „be pakitimu““). Paveiksliuke grafiškai pavaizduoti tyrime dalyvavusių pacientų 1,5T ir 3T galvos MRT tyrimų rezultatai.

1,5T galvos smegenų MRT tyrimų metu patologija nustatyta 39 moterims ir 22 vyrams, $3 \mathrm{~T}$ galvos smegenu MRT tyrimų metu patologija nustatyta 55 moterims ir 34 vyrams, t. y. 3T galvos MRT tyrimų metu 6,85 \% dažniau rasta galvos smegenų patologija nei tų pačių pacientu 1,5T galvos MRT tyrimų metu, santykinio dažnio pasikliautinasis intervalas - nuo 6 iki $7 \%$.

Didžioji 1,5T galvos MRT vaizdus vertinusių gydytojų radiologų dalis buvo bendrosios specializacijos, todèl dèl nepakankamos imties negalime įvertinti priklausomybès $\operatorname{tarp}$ 1,5T galvos MRT radinių (ir atskirų jų rūšių) bei gydytojų radiologo specializacijos. 3T galvos MRT radinių $(\mathrm{p}=0,569)$ bei atskirų patologijos rūšiu $(\mathrm{p}=0,104)$ nustatymo dažnis nepriklauso nuo gydytojo radiologo specializacijos. 


\section{REZULTATU APTARIMAS}

Šio tyrimo rezultatai iš dalies prieštarauja J. von Oertzen su bendraautoriais atlikto tyrimo rezultatams galimai dèl per mažos ị tyrimą įtrauktos gydytojų neuroradiologų imties. Autoriai retrospektyviai vertino ryši tarp epilepsija sergančių pacientų standartinio galvos smegenų MRT tyrimo bei epilepsijai specialių galvos smegenų MRT tyrimų rezultatų ir juos vertinusių gydytojų radiologų patirties epilepsijos diagnostikos srityje [6]. I tyrimą pradžioje buvo įtraukti 536 pacientai, tačiau visus kriterijus atitiko tik 123 epilepsija sergantys ir chirurginiu būdu gydyti pacientai, radiologiškai tirti nuo 1996 m. sausio mèn. iki 1999 m. birželio mèn. Lyginti rezultatai tarp standartinių galvos smegenų MRT tyrimų, interpretuotų bendrosios specializacijos gydytojų radiologų, standartinių galvos smegenų MRT tyrimų, interpretuotų epilepsijos diagnostikos patirties turinčių gydytojų radiologų (t. y. neuroradiologų), ir neuroradiologų, vertinusių epilepsijai specialių galvos smegenų MRT tyrimų vaizdus. Išanalizavę duomenis, autoriai gavo, kad bendrosios specializacijos gydytojų radiologų, vertinusių standartinius MRT tyrimus, išvadų apie židininị pažeidimą jautrumas yra $39 \%$, neuroradiologų, vertinusių standartinius MRT tyrimus, išvadu jautrumas - $50 \%$, o neuroradiologų, vertinusių epilepsijai specifiškus MRT tyrimus, išvadų jautrumas - $91 \%$. Epilepsijai specialūs galvos smegenų MRT tyrimai aptiko židininius pažeidimus $85 \%$ atvejų tiems pacientams, kuriems nerasta pakitimų standartinio galvos smegenų MRT tyrimo metu. Bendrosios specializacijos gydytojai radiologai, vertindami standartinio galvos MRT tyrimo vaizdus, dažniau nei neokortikalinius pokyčius praleido medialinès temporalinès skilties anomalijas. Daugiausia neidentifikuota hipokampo sklerozès atvejų - net $86 \%$. Neuropatologinès diagnozès ( $\mathrm{n}=90$ ) teisingai buvo nustatytos $22 \%$ atvejų bendrosios specializacijos gydytojų radiologų standartinių MRT tyrimų išvadose ir net $89 \%$ - epilepsijai specifiškų MRT tyrimų išvadose. Reikia atkreipti dėmesį, kad laiko tarpas tarp standartinio ir epilepsijai specialaus galvos smegenų MRT tyrimo vidutiniškai buvo apie 22 mèn. Tai daugiau nei 2 kartus trumpesnis laikas tarp tyrimų, lyginant su VUL SK atliktais tyrimais. Anot autoriu, ilgas laukimo intervalas tarp galvos smegenų MRT tyrimų galëjo neigiamai paveikti epilepsijai specialios MRT rezultatus. Oertzen pabrèžè, kad standartinio galvos smegenų MRT tyrimo metu nebuvo nustatyta $57 \%$ epileptogeninių pažeidimų, ir reziumavo, kad pacientai, kuriems įtariama refrakterinè epilepsija, turètų būti nukreipti ị radiologijos centrą, ištirti pagal epilepsijai specifišką MRT protokolą ir gauti radiologiniai vaizdai aprašyti epilepsijos diagnostikos patirties turinčių gydytojų radiologų.

Praejjus $6 \mathrm{~m}$. nuo J. von Oertzen ir kitų bendraautorių tyrimo rezultatu paskelbimo, Pramit M. Phal ir kt. atliko retrospektyvini tyrimą, kurio tematika ir tikslas atitinka mūsų darbo metu užsibrèžtą tikslą [7]. Tyrẻjai siekẻ ịrodyti, kad 3T galvos smegenų MRT tyrimas yra potencialiai jautresnis ir specifiškesnis nei 1,5T galvos smegenų MRT tyrimas, nustatant epileptogeninius židinius, ir gali turèti ịtakos planuojant refrakterinès epilepsijos chirurgini gydymą. Autoriai analizavo 25 pacientu galvos smegenų vaizdus (iš viso - 50 vaizdų), kurie atlikti 1,5T ir 3T stiprumo magnetinio rezonanso skaitytuvais pagal specialu epilepsijos protokolą, taikant 4 skenavimo sekas: T2-weighted, coronal FLAIR, coronal fast multiplanar inversion recovery ir $3 D$ spoiled gradient-recalled echo. Vaizdai vertinti pagal 4 parametrus: vaizdų iškraipymą, pažeidimo vizualizavimą, pilkosios ir baltosios medžiagų diferenciaciją ir judesio artefaktus. Nustatyta, kad 3T galvos smegenų MRT tyrimas visose 4 sekose statistiškai reikšmingai $(\mathrm{p}<0,05)$ geresnis už $1,5 \mathrm{~T}$ galvos smegenų MRT tyrimą pagal visus parametrus, išskyrus judesio artefaktus. 3T galvos MRT tyrime patologiniai pakitimai buvo nustatyti 65 atvejais iš 74 (88\%), o 1,5T MRT tyrimo metu patologiniai pokyčiai aptikti tik 55 iš 74 atvejų (74 \%) $(\mathrm{p}=0,0794)$. Patikimumo koeficientų skirtumas parode, kad epileptogeninio židinio nustatymą 2,57 karto dažniau ir 2,66 karto tiksliau apibūdina 3T galvos MRT, lyginant su 1,5T MRT technologija. Šio tiriamojo darbo išvada patvirtina ir papildo anksčiau atliktų tyrimų išvadas: epilepsijos radiologineje diagnostikoje 3T galvos smegenų MRT tyrimas yra patikimesnis nei 1,5T galvos smegenų MRT tyrimas pagal vaizdo kokybę, struktūrinių pažeidimų radimą ir pažeidimų apibūdinimą. Pacientams, sergantiems sunkiai gydoma epilepsija, neradus patologijos ar gavus nevienareikšmes 1,5T galvos MRT tyrimo išvadas, reikètų pagalvoti apie didesnio magnetinio lauko stiprumo MRT tyrimą. Mes savo darbu taip pat statistiškai reikšmingai įrodème 3T galvos smegenų MRT tyrimo pranašumą, nors, galimai dèl mažesnès tiriamujjų apimties, gavome ne tokị ryškų diagnostinį skirtumą.

Kitas panašios tematikos, metodikos ir mūsų darbo rezultatus didesnejje pacientų grupejje patvirtinantis tyrimas priklauso Gavin P. Winston ir bendraautoriams [8]. Jie atliko retrospektyvinę apžvalgą, kuria taip pat siekẻ palyginti skirtingo magnetinio laukos stiprumo (1,5T ir 3T) galvos smegenų MRT tyrimų patikimumą epilepsijos diagnostikoje. Jų tyrimo metu buvo vertinti kartotinių MRT tyrimų metu gauti vaizdai, didinant magnetinio lauko stiprumą nuo 1,5T iki 3T bei pritaikant patobulintas galvos rites tam, kad būtų aptiktos anksčiau nepastebètos patologijos. I tyrimą įtraukta didelè pacientų grupė $(n=804)$, kuriems tretiniame epilepsijos diagnostikos centre 1995-2004 m. buvo atlikti 1,5T galvos smegenu MRT tyrimai, o vèliau 2004-2011 m. - 3T galvos smegenų MRT tyrimai su patobulintomis galvos ištyrimui pritaikytomis ritemis. Židinine epilepsija sirgo $87 \%$ tiriamuju, generalizuota epilepsija $-8 \%$, o neklasifikuojama epilepsija - $5 \%$ tiriamujų. Atliekant 3T magnetinio lauko stiprumo galvos smegenu MRT tyrimus, $37 \%$ atvejų nerasta patologijos, o $20 \%$ diagnozuoti atsitiktiniai radiniai. Generalizuota epilepsija sergantys pacientai taip pat įtraukti i šią grupę. Dažniausiai nustatytos patologijos buvo: hipokampo sklerozė (13\%), žievės vystymosi malformacijos (8\%), kitos anomalijos $(4 \%)$ ir pooperaciniai galvos smegenų pakitimai (18\%). 3T MRT tyrimo vaizduose rasti 97 (12\%) nauji pažeidimai, kurių nebuvo pastebèta tiriant $1,5 \mathrm{~T}$ magnetinio rezo- 
nanso skaitytuvais. Didžioji dalis naujai diagnozuotų pakitimų buvo atsitiktiniai radiniai, bet vizualizuoti 37 (5\%) patologiniai židiniai, kurie nebuvo nustatyti atliekant 1,5T MRT tyrimus: hipokampo sklerozè, židininès žievès displazijos ir DNET.

\section{IŠVADOS IR PRAKTINĖS REKOMENDACIJOS}

Mūsų atlikto tyrimo rezultatai rodo, kad gydytojų radiologų specializacija nelemia dažnesnio ir patikimesnio galvos smegenų pakitimų ir atskirų jų rūšių nustatymo; 3T galvos smegenų MRT dažniau ir patikimiau nustato patologinius su epilepsijos priepuoliais susijusius židinius, todèl ji turètų būti atliekama visiems vaistams atsparia epilepsija sergantiems pacientams, kuriems prieš tai atliktų 1,5T galvos smegenų MRT tyrimų metu pakitimų nerasta ar pateikiamos nevienareikšmès išvados; 3T galvos smegenų MRT geriau atskleidžia hipokampo sklerozę, žievès vystymosi malformacijas ir kitus patologinius pakitimus, lyginant su 1,5T galvos smegenų MRT tyrimu, todèl sunkia epilepsijos forma sergantiems pacientams neurovizualiniai tyrimai turètų būti atliekami didelès skiriamosios gebos magnetinio rezonanso tomografais, keliose plokštumose ir laikantis specialaus epilepsijos diagnostikos protokolo.

\section{Literatūra}

1. International League Against Epilepsy 2018. [žiūrèta 2018-04-03]. Prieiga per: https://www.ilae.org/about-ilae

2. Bajorinaitė A, Laurinkienė J, Dementavičienè J. Epilepsijos vaizdinimas. Medicinos teorija ir praktika 2013; 19(3.1): 166-71.

3. Grant PE. Imaging the developing epileptic brain. Epilepsia 2005; 46(7): 7-14. https://doi.org/10.1111/j.1528-1167. 2005.00303.x

4. Daghistani R, Widjaja E. Role of MRI in patient selection for surgical treatment of intractable epilepsy in infancy. Brain \& Development 2013; 35(8): 697-705. https://doi.org/ 10.1016/j.braindev.2013.03.009

5. Blümcke I, Spreafico R, Haaker G, Coras R, et al. Histopathological findings in brain tissue obtained during epilepsy surgery. The New England Journal of Medicine 2017; 377: 1648-56. https://doi.org/10.1056/NEJMoa1703784

6. Von Oertzen J, Urbach H, Jungbluth S, et al. Standard magnetic resonance imaging is inadequate for patients with refractory focal epilepsy. Journal of Neurology, Neurosurgery, and Psychiatry 2002; 73(6): 643-7. https://doi.org/10.1136/ jnnp.73.6.643

7. Phal PM, Usmanov A, Nesbit GM, Anderson JC, et al. Qualitative comparison of 3-T and 1.5-T MRI in the evaluation of epilepsy. Neuroradiology 2008; 191: 890-5.

8. Winston GP, Micallef C, Kendell BE, et al. The value of repeat neuroimaging for epilepsy at a tertiary referral centre: 16 years of experience. Epilepsy Research 2013; 105: 349-55. https://doi.org/10.1016/j.eplepsyres.2013.02.022

\section{Runkauskaitė, T. Liakina, R. Mameniškienė}

\section{COMPARISON OF $3 \mathrm{~T}$ AND 1.5 T MRI IN THE EVALUATION OF EPILEPSY}

\section{Summary}

Background. Epilepsy is the fourth most common neurological disorder characterized by a long-term tendency to generate epileptic seizures due to excessive or synchronous activity in the neurons in brains. Most patients achieve adequate seizure control by taking antiepileptic drugs and have a good medication effect, however $20-30 \%$ of patients continue suffering from recurrent epileptic seizures. Magnetic resonance imaging (MRI) is the most basic and informative neurovisual approach for the diagnosis of epileptogenic foci and their types. A detailed neurovisual examination of the brain is particularly important in patients with refractory epilepsy who may be considered as option candidates for surgical treatment.

Materials and methods. 164 patients (99 women and 65 men) were enrolled in the study who underwent 1.5 T MRI and $3 \mathrm{~T}$ MRI at Radiology and Nuclear Medicine Centre of Vilnius University Hospital Santaros klinikos. The pathological findings and the frequency of their detection with different magnetic field strengths of MRI were evaluated.

Results. A statistically significant relationship $(\mathrm{p}<0.001)$ was found between magnetic field strength of MRI examination and the frequency of detecting pathological findings, but there was no statistically significant relationship $(p=0.183)$ between magnetic field strength of MRI and the the frequency of determining the type of epileptogenic foci.

Conclusions. 3 T MRI more often and more accurately detects pathologies associated with epileptic seizures therefore it is recommended for patients with epilepsy or for those patients in whom the previous $1.5 \mathrm{~T}$ MRI could not identify pathology or showed mixed results.

Keywords: epilepsy, focal epilepsy, magnetic resonance imaging, $3 \mathrm{~T}$ magnetic resonance imaging.

Gauta:

20180826
Priimta spaudai: 20180920 